\title{
"Nexus of firm characteristics and financial performance of non-life insurance companies in the Southern African Development Community"
}

\begin{tabular}{|c|c|}
\hline AUTHORS & $\begin{array}{l}\text { Thabiso Sthembiso Msomi (i) } \\
\text { Celani John Nyide (iD) }\end{array}$ \\
\hline ARTICLE INFO & $\begin{array}{l}\text { Thabiso Sthembiso Msomi and Celani John Nyide (2021). Nexus of firm } \\
\text { characteristics and financial performance of non-life insurance companies in the } \\
\text { Southern African Development Community. Investment Management and } \\
\text { Financial Innovations, 18(4), 95-110. doi:10.21511/imfi.18(4).2021.09 }\end{array}$ \\
\hline DOI & http://dx.doi.org/10.21511/imfi.18(4).2021.09 \\
\hline RELEASED ON & Friday, 22 October 2021 \\
\hline RECEIVED ON & Thursday, 12 August 2021 \\
\hline ACCEPTED ON & Friday, 08 October 2021 \\
\hline LICENSE & $\begin{array}{l}(c)) E Y \\
\text { This work is licensed under a Creative Commons Attribution } 4.0 \text { International } \\
\text { License }\end{array}$ \\
\hline JOURNAL & "Investment Management and Financial Innovations" \\
\hline ISSN PRINT & $1810-4967$ \\
\hline ISSN ONLINE & $1812-9358$ \\
\hline PUBLISHER & LLC "Consulting Publishing Company "Business Perspectives" \\
\hline FOUNDER & LLC "Consulting Publishing Company "Business Perspectives" \\
\hline
\end{tabular}

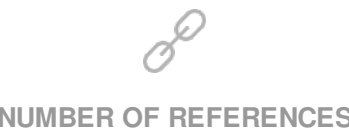

81

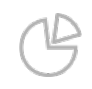

NUMBER OF FIGURES

1

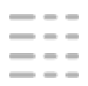

NUMBER OF TABLES

4

(C) The author(s) 2021. This publication is an open access article. 


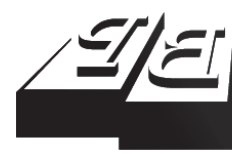

\section{BUSINESS PERSPECTIVES}

(O)

LLC "CPC "Business Perspectives" Hryhorii Skovoroda lane, 10, Sumy, 40022, Ukraine www.businessperspectives.org
Received on: $12^{\text {th }}$ of August, 2021 Accepted on: $8^{\text {th }}$ of October, 2021 Published on: $22^{\text {nd }}$ of October, 2021

(c) Thabiso Sthembiso Msomi, Celani John Nyide, 2021

Thabiso Sthembiso Msomi, Master of Accounting, Lecturer, Accounting and Informatics Faculty, Management Accounting Department, Durban University of Technology, South Africa. (Corresponding author)

Celani John Nyide, Senior Lecturer, Ph.D., Faculty of Accounting and Informatics, Department of Finance and Information Management, Durban University of Technology, South Africa.

NEXUS OF FIRM CHARACTERISTICS AND FINANCIAL PERFORMANCE OF NON-LIFE INSURANCE COMPANIES IN THE SOUTHERN AFRICAN DEVELOPMENT COMMUNITY

\begin{abstract}
In almost all emerging and developed nations, the insurance industry is one of the most important participants of the financial services sector. As a result, the goal of this study is to investigate the firm characteristics and drivers of financial performance using 121 publicly traded non-life insurance companies from 16 Southern African Development Community (SADC) countries during the period from 2008 to 2019. The consolidated least squares and two-step generalized method of moments estimators were used to analyze a panel data set of 1,452 observations. The findings show that a lagged return on assets, equity capital, operational efficiency, leverage and investment capability are statistically significant determinants of financial performance in non-life insurance companies of SADC countries, even though equity capital, operational efficiency, and leverage are inversely significant. The insurance industry, policymakers, the state, and shareholders should consider these important variables when making decisions, and enhance their performance according to the findings. It is also suggested that the in dustry's capital structures should be reformed to preserve a favorable balance of equity and debt amongst the businesses. Additionally, measures such as automated systems that may decrease operating costs should be used to improve financial performance.
\end{abstract}

\title{
Keywords
}

non-life insurance, firm characteristics, financial performance, two-step estimator, generalized method of moments, regression

\section{JEL Classification $\quad$ C23, F65, G22, L25}

\section{INTRODUCTION}

The success of every company not only contributes to its market value but also to the development of the entire sector, which in turn contributes to the economy's general prosperity (Mwakajila \& Nyello, 2021). Mostly in the finance literature, evaluating the factors that contribute to insurance companies' performance has attracted interest because as mediators, these businesses not only provide a framework for risk transfer but also assist in channeling funds in an appropriate manner to create sustainable activities in the economy (Burca \& Batrinca, 2014). These have however garnered scant recognition, especially in emerging countries. Academics in different fields of operational and organizational management have paid close attention to the topic of financial performance. Financial performance has consequences for an organization's health and eventually its survival, and it has been a major concern of business practitioners in all kinds of companies (Egbunike \& Okerekeoti, 2018). High performance shows managerial effectiveness and efficiency in using a resource of the company, which benefits the whole economy of the nation (Egbunike \& Okerekeoti, 
2018). In respect of both conceptualization and measurement, performance is a tough notion to grasp (Mwakajila \& Nyello, 2021). It has been described as the outcome of an activity, as well as the proper metric to assess corporate performance, and is said to be dependent on the kind of company to be reviewed and the goals to be accomplished via that assessment (Burca \& Batrinca, 2014). General insurance firms are beneficial to both businesses and people because they offer social and economic advantages to society, such as increased employment and reduced anxiety and dread.

In underdeveloped and developing countries like the Southern African Development Community (SADC), economic growth is a critical method for alleviating widespread poverty (Nhabinde \& Heshmati, 2020). Over time, the financial sector has worsened, which is incompatible with SADC's modest economic development. Consequently, financial systems are unstable and underdeveloped at their core. At the center of the unstable and stagnant development of financial systems is the poor performance of non-life insurance companies (Egbunike \& Okerekeoti, 2018). The insurance market in SADC faces numerous issues such as low-penetration restrictions, low pay, profound ignorance and trust, elevated levels of financial exclusion, a lack of infrastructure and channels of distribution, a lack of internal skills and information, negligible coverage opportunities, substantial obstacles to retail individualization, increased burdensome regulations for liberalization, and regulatory disadvantage and smoothness (Asongu et al., 2019). These necessitate the importance of examining the firm's characteristics (such as equity capital, company age, company size, underwriting risk, operational efficiency, claim ratio, leverage ratio, liquidity ratio, and investment capabilities), as well as firm's financial performance. In SADC, the dearth of a regulating authority has culminated in the insurance industry's poor performance over the last couple of years, with many companies closing due to a lack of capital (Olarewaju \& Msomi, 2021). As a result, the Insurance Regulatory Authority was established, which is a governmental agency that regulates, promotes, and oversees SADC's insurance sector. Notably, insurance firms' earnings have been declining in recent years (Olarewaju \& Msomi, 2021). In addition, the influence of firm characteristics on firm performance is adequately supported by past research.

Contrasting findings have been reached in the literature on the connection between company characteristics and firm performance (Mazviona et al., 2017; Ibrahim et al., 2018; Mwakajila \& Nyello, 2021; Egbunike \& Okerekeoti, 2018; Kaur \& Kaur, 2019; Junaid et al., 2020). There have been few studies on the effects of equity capital, company age, company size, underwriting risk, operational efficiency, claim ratio, leverage ratio, liquidity ratio, and investment capabilities on the performance of publicly-traded businesses. The goal of an optimum feature is to maximize the company or market value, improve profitability, reduce risk and minimize the weighted average cost of capital. If companies are unable to attain the maximum financial performance through optimal firm characteristics, it becomes a cause for concern.

Notwithstanding the growth of non-life insurance firms, few studies have been performed to evaluate their performance in the SADC area. The factors of performance have been examined in finance literature for ages, but no research on non-life insurance businesses has been done. The study of the connection between firm characteristics and non-life insurance industry financial performance offers useful information for evaluating the performance determinants of non-life insurance businesses in established and emerging countries. As a result, the importance of this study is to fill a vacuum in one's knowledge of the drivers of non-life insurance firms' financial success in the SADC region.

The study's goal is to provide financial managers with practical information for identifying the factors that influence non-life insurance performance because of their financial management, control, and verdict. The paper will also contribute to the body of knowledge in the finance discipline, serve as a basis for further development of the results, and as a future source of reference for academicians. Individuals interested in purchasing insurance policies, as well as investors interested in investing in the life insurance business, may use this analysis to choose a firm from amongst the numerous rivals. 
Financial advisers may use the results of the study to advise their customers on which businesses to invest in to fulfill their expectations. Clients and investors would be well informed if the bigger nonlife insurance firms paid greater dividends. In summary, this study fills a vacuum in the current literature by looking at the internal variables that affect the insurance company performance in SADC countries.

\section{LITERATURE REVIEW}

\subsection{Synopsis of non-life insurance companies in the Southern African Development Community}

The Southern African Development Community (SADC) is an inter-governmental body. It aims to promote regional socio-economic synchronization and economic and policy cooperation across 16 southern African nations (Olarewaju \& Msomi, 2021). In 1992, 16 nations formed SADC. SADC is committed to regional integration and poverty reduction in Southern Africa, as shown by economic development as well as security and prosperity (Mlambo, 2020). SADC comprises several developing and rising countries, with the insurance industry continuing to expand at a rapid pace (Nhabinde \& Heshmati, 2020).

Nonetheless, the region's broader economic prosperity has indeed been able to progressively create growth possibilities for the insurance sector in recent years. One of the main factors propelling the insurance industry in Southern Africa has been the development of numerous emerging markets (Asongu et al., 2019). However, the lack of insurance coverage in SADC suggests a significant rise in the risk (Nhabinde \& Heshmati, 2020). Even though there are some outliers, regulatory hurdles are often extremely low, and regulations are less onerous. The population health of the SADC nations is strengthening and Southern Africa has a large youthful population. Nevertheless, the potential downsides of doing business with SADC should never be ignored (Nhabinde \& Heshmati, 2020). Political instability, incompetence, poor infrastructure, complexity, stricter regulations, and stagnation may not seem to overwhelm positive characteristics, but they all represent significant dangers throughout the country (Nhabinde \& Heshmati, 2020). According to a Finmark Trust (2019) study, $94.5 \%$ of the population in the area is not formally self-insured, which means that the insurance industry has enormous development potential. South Africa has the finest emerging markets in the area, with a well-organized stock exchange and a sizeable bond market (Alhassan \& Biekpe, 2017). Furthermore, Africa is steadily moving toward a more secure future, with overwhelming support for the insurance industry as a means of ensuring the economy's long-term viability and growth (Olarewaju \& Msomi, 2021). This promotes saving as well as spending, employment creation, and capital and financial market growth. According to Padayachee et al. (2019), the insurance business in Africa remains one of the most challenging, but industry leaders continue to evolve and suggest improvements in order to fully exploit the many possibilities for development that are currently arising.

\subsection{Hypotheses development: firm-specific determinants of insurers' financial performance}

Performance may be defined as the result obtained while engaging in a certain activity (Mwakajila \& Nyello, 2021). The metric used to assess performance in the business sector is determined by the kind of company being assessed and the goal of the review (Mazviona et al., 2017). This acts as a benchmark for determining the most suitable performance metric. Researchers in the area of strategic management have proposed several approaches for analyzing financial performance (Burca \& Batrinca, 2014). The use of multiple models or relationship patterns amongst company effectiveness and its determinants, according to the multidisciplinary perspective of performance, will result in varied relations between dependent combined with independent factors in the estimated models (Badea, 2017).

There are two types of performance, which are financial and non-financial performance (Saeidi et al., 2018). Moreover, financial and economic performance is usually distinguished from creative 
performance. Financial success is often expressed in terms of sales growth, turnover, or stock prices (Yassin, 2021). Traditionally, inventive performance has been measured in terms of inventions, expenditure, and innovative sales percentages, as well as self-reported innovation outcomes.

Liquidity ratios and profitability ratios are the two types of ratios used to assess the success of a company. The profitability ratio is a popular performance metric. Return on assets (ROA), net profit margin, return on equity (ROE) and gross profit margin are all examples of profitability ratios. Return on assets (ROA) was employed as a proxy for performance following Ahmed, Khalid, Ahmed and Shah (2017), Burca and Batrinca (2014), Mwangi and Murigu (2015), Berteji and Hammami (2016), Alomari and Azzam (2017), Berhe and Kaur (2017), Mazviona et al. (2017), Ibrahim et al. (2018), Mwakajila and Nyello (2021).

Return on assets (ROA) is a metric that measures company's financial performance in relation to its total assets (Aliabadi et al., 2013). It indicates whether the company management has been effective in producing profits by utilizing the company assets. Epps and Cereola (2008) state that return on assets (ROA) is by far the most suitable indicator of company performance, and a rise in the ROA ratio indicates that the related firm is doing well financially, and vice versa.

Leverage: The ratio of debt to equity in a company's capital structure is referred to as leverage (Padmavathi \& Thangadurai, 2016). It aims to determine how much of the overall assets are funded by borrowed money. According to Padmavathi and Thangadurai (2016), leverage ratios are used to assess company commercial and financial risks. Leverage and company size have been proven in various studies to have a great significant connection (Zuhroh, 2019; Nnenna et al., 2020). The amount of debt utilized to fund other capital expenditures that may enhance company's financial performance is referred to as leverage. The ratio of total debt to equity (debt/equity ratio) is a metric of debt leverage. This ratio shows the amount of money borrowed by a company. It refers to an insurance company's capacity to sustain its market risk in the face of unexpected occurrences (Egbunike \& Okerekeoti, 2018). This ratio depicts the possible effect of financial demands on capital and the excess of reserve shortfalls (Adams \& Buckle, 2003).

Liquidity: Another factor that influences financial performance is liquidity. Liquidity, according to the Business Dictionary, is the degree to which debt obligations are due within the next 12 years. The capacity of an insurer to meet its prompt commitments to policyholders without needing to raise earnings from underwriting and investment operations or liquidate financial assets is referred to as insurance liquidity (Kariuki \& Nguyo, 2020). Moreover, cash and bank balances must be sufficient to satisfy immediate obligations in respect of claims that are due, but that have not yet been paid. Malik (2011) came to a contrary conclusion, that leverage was adversely linked to financial performance. Batool and Sahi (2020), on the other hand, indicate that although the connection is beneficial, it is insignificant since a change in leverage has little effect on financial performance if everything else is comparable.

Size of a company: Another key element in influencing the financial performance of an insurance business is its size because the size of a company has a variety of effects on its financial success. When equated to conventional businesses, large corporations may benefit from economies of size and scope, making them more efficient (Bashatweh \& Ahmed, 2020). The net premium, which is the premium earned by the insurance company after deducting the reassurance provided, determines the size (Killins, 2020). Their premium base, according to Teece et al. (2016), determines the number of insurance obligations that insurers must bear. Mehari and Aemiro (2013) states that it is statistically significant, according to Malik (2011), and is positively linked to ROA. In order to attain the greatest financial performance, insurance firms would increase their asset volume owing to the direct correlation between size and profitability.

Age of a company: Another important factor is the age of the insurers. Older companies have much more experience, have benefitted from knowledge, are less vulnerable to new liabilities, and can therefore recognize better performance (Lingesiya, 2020). Older companies may profit from reputational impacts, which enable them to increase 
their sales margins. On the other hand, older businesses are more susceptible to the inefficiencies and bureaucratic ossification that comes with age and they may have established habits that are out of sync with changing market circumstances, resulting in an adverse connection between age as well as financial performance or success (Kaur \& Kaur, 2019; Junaid et al., 2020).

Underwriting of risk: The underwriting of risk, which indicates the sufficiency or otherwise of insurers' underwriting performance, is another element that influences financial success (Batool \& Sahi, 2020). Hence, the insurer's financial success is dependent on sound underwriting standards. The risk of underwriting is determined by the insurance companies' risk tolerance (Batool \& Sahi, 2020). The benefit-to-net-premium ratio is an indicator of systematic underwriting risk.

Operational efficiency: Oppong et al. (2019) state that performance is a factor that mediates the relationship between company operational and strategic efficiency. The company's primary goals are to strengthen manufacturing processes, as well as to improve quality, product, and market management. In addition, the profitability of a company is determined by its financial performance. The gross margin rate, return on assets, and return on equity are all metrics that may be used to evaluate company's financial success (Oppong et al., 2019). Any kind of firm operational efficiency is critical, and management must take this into account to produce solid and long-term financial results. The capacity of a company to minimize costs and optimize resource capabilities in order to provide high-quality products and services to consumers is known as operational efficiency (Musah et al., 2019). The firm's financial success is critical in attracting the attention of academics, financial specialists, and other company executives. It is a difficult job to choose a successful business, which is why they must be worried about the company's financial performance. The financial performance of the insurance sector is critical to many parties, particularly agents as well as policy-makers, according to Wongchai (2017).

Claims ratio: This ratio compares the amount of compensation including commission paid by the business to the sum of premiums collected and re-insurer commission earned by the company
(Abdeljawad et al., 2020). The claims ratio is one of the main drivers of underwriting financial performance, and this study looked at it as a firm-specific factor influencing the performance of the insurance company. The claim ratio was shown to be a major predictor of insurance company financial performance by Mwangangi (2020).

Investment capability: The importance of investment in the firm's financial success cannot be overstated. Businesses invest their resources in the hopes of generating a profit that will motivate them to enhance their financial performance. Njeru (2018a), who believes that there is a positive connection between investment and the degree of financial success attained by the business, supports this viewpoint. He claims that the impact of an investment on a company's financial success may be transitory rather than long-term. Njeri (2017) also shows how interest-bearing and interest-free investments work together to improve company's monetary success. Rajapathirana and Hui (2018), on the other hand, argue that investment should be seen through the lens of research and development. They believe that many of the dollars spent on research and development by a company may enhance the investment as well as the company's financial success (Njeru, 2018b). It is believed that investing in research and development increases a company's future profits. Hence, the following hypotheses are drawn:

H1: Leverage does not determine the financial performance of non-life insurance companies in the SADC region.

H2: Liquidity does not determine the financial performance of non-life insurance companies in the SADC region.

H3: Company size does not determine the financial performance of non-life insurance companies in the SADC region.

H4: Company age does not determine the financial performance of non-life insurance companies in the SADC region.

H5: Underwriting risk does not determine the financial performance of non-life insurance companies in the SADC region. 
INDEPENDENT VARIABLES

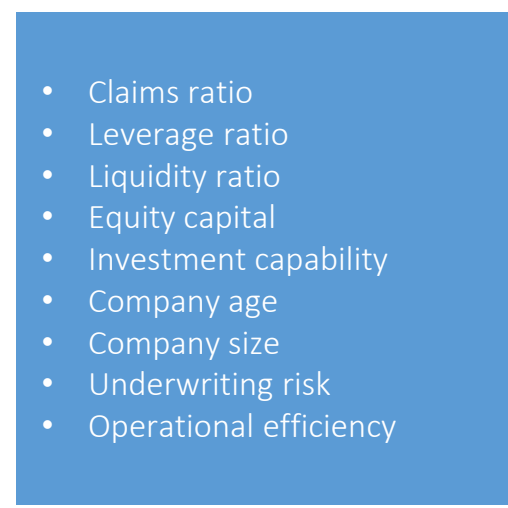

DEPENDENT VARIABLE

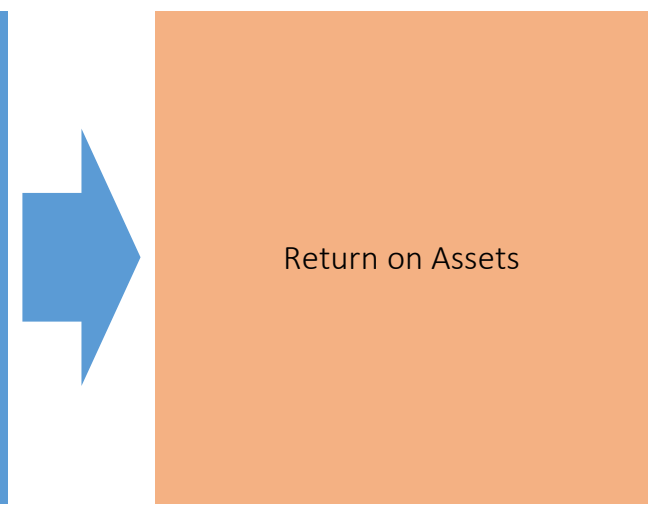

Figure 1. Conceptual model

H6: Operational efficiency does not determine the financial performance of non-life insurance companies in the $S A D C$ region.

H7: Claims ratio does not determine the financial performance of non-life insurance companies in the SADC region.

H8: Investment capability does not determine the financial performance of non-life insurance companies in the $S A D C$ region.

\subsection{Conceptual model}

Figure 1 illustrates the conceptual model underpinning this study. This model demonstrates the relationship between the independent and dependent variables.

\subsection{Theoretical framework}

Agency theory: The principal-agent problem, also known as the agency conundrum, happens when an individual or organization (the "agent") has the authority to make choices on behalf of an individual or organization (the "principal"). The quandary emerges because the agent is sometimes inclined to behave with his own best interests rather than those of the principal. Although the dispute between managers and owners over the company's operation has been extensively researched, research on recognizing the distinctions in response to various shareholder orientations is scarce. According to Berle and Means argument in Davis (2010), when managerial competence increases, organizations may be running for the advantage of the managers instead of the proprietors. According to Berger and Humphrey (1997), the reasons underlying the operating performance of financial services organizations are frequently hard to distinguish due to the intangible character of outputs as well as the lack of oversight within resource allocation. Conversely, finance literature study results, including those given by agency theory, provide valuable insights into the characteristics of organizational performance in financial services companies. As a result, financial efficiency is determined by the efficiency of contractual frameworks in attracting, maintaining, and regulating management talent in ways that maximize the shareholder's wealth. Numerous studies have used agency theory to determine the financial performance of the company with a separation of ownership and management. Agency control measures have been implemented to synchronize managers' (agents') aims with that of owners (principals). The expenditures of all operations and operating systems meant to synchronize management goals and objectives with the interests of owners are referred to as agency costs. The effectiveness of the company assets, the method wherein the firm finances its interaction, whether with equity or debt, the appropriate absorbing of a premium collected by this insurance company, the managerial staff of the company's policy as it applies to immunizing the insurance company, as well as the capacity of the insurers to generate stable liquidity within the organization to meet its everyday activities as they arose.

Stewardship theory: The stewardship idea lies at the heart of this study. Through company financial performance and utilitarian metrics, the the- 
ory preserves and maximizes shareholder value. Stewards are firm managers who work for the benefit of the shareholders by safeguarding their interests and maximizing profits. According to this idea, stewards will be pleased and motivated if the organizational goal of success is met. It stresses the ability of workers or executives to operate independently in order to derive maximum investment returns. According to Daly et al. (2003), the costs of monitoring and surveillance behavior patterns can be reduced, and the board of directors is discarded to continue operating the organization to improve the financial performance or returns on investment of the shareholders to safeguard the credibility of the shareholders and the company as decision-makers. As a result, it is thought that financial performance has a direct effect on personal performance judgments. Furthermore, the idea argues that the chairman and chief executive officer have a unique responsibility to play in lowering agency expenses in order to increase the firm's returns and protect the interests of the shareholders.

The goal of this study is to fill a void in the literature by examining how variables such as claim ratio, leverage ratio, liquidity ratio, equity capital, investment capability, company age, company size, underwriting risk, and operational efficiency affect financial performance in SADC nations. It will be critical to offer recommendations based on the findings on how to improve the financial performance of non-life insurance companies.

\section{EMPIRICAL MODEL, DATA AND METHODOLOGY}

Secondary data from 2008 to 2019 was used in this paper. Considering that the SADC insurance sector has been under pressure since the global financial crisis of 2008, the year 2008 was selected ${ }^{1}$. S\&P CapitallQ, Refinitiv Eikon, and the financial statements of the different firms were used to gather the necessary firm-specific data. As a result, the study's findings came primarily from a content analysis of the companies' annual reports. This is a 12-year regional analysis with 1,452 observations of 121 insurers from 16 SADC nations. Panel studies were justified and recommended because of their capacity to account for behavioral differences over time, cross-sectional, manage heterogeneity issues, and allow for more parameter estimation (Greene, 2003; Kutu \& Ngalawa, 2016). Owing to the accessibility of data for the study period, the companies used were chosen with care.

The Blundell and Bond (1998) two-step GMM system was used as the estimating technique based on its ability to cater to cross-sectional dependency problems. Two estimators, one-step and two-step, were proposed by Arellano and Bond (1991). It was affirmed that the two-step estimator is optimal and more efficient. Thus, the use of the two-step SYS-GMM was employed to estimate the coefficients of the determinants of financial performance of listed non-life insurance companies in SADC. Furthermore, the serially correlated errors are catered for using the 1 and 2 tests for autocorrelation in the idiosyncratic disturbance term as incorporated in the two-step GMM estimator. Moreover, the reliability of the estimation in this study is justified using the Hansen or Sargan test, which is the test used for the instrument validity check.

Model specification: The relationship between the internal and external factors that affect the financial performance of SADC insurance companies was depicted using the expression below. The linear relationship between dependent and independent variables is shown as:

$$
Y_{i t}=\alpha+\beta^{\prime} X_{i t}^{\prime}+\mu_{i t} .
$$

Since there are categories of determinants (firm characteristics), the model will lead to:

$$
Y_{i t}=\alpha_{0}+\beta_{i} X_{A i t}+\beta_{i} X_{B i t}+\mu_{i t}
$$

where $X_{A i t}$ denotes macroeconomic variables; $X_{B i t}$ denotes the firm-specific variables.

Explicitly,

$$
\begin{aligned}
& Y_{i t}=\alpha_{0}+\beta_{1} X_{1 i t}+\beta_{2} X_{2 i t}+\beta_{3} X_{3 i t}+ \\
& +\beta_{4} X_{4 i t}+\beta_{5} X_{5 i t}+\beta_{6} X_{6 i t}+\beta_{7} X_{7 i t}+ \\
& +\beta_{8} X_{8 i t}+\beta_{9} X_{9 i t}+\mu_{i t},
\end{aligned}
$$

where $X_{B i t}$ is represented as $X_{1}-X_{9}$.

1 https://www.consultancy.africa/news/975/africas-insurance-sector-is-struggling-against-tech-and-regulatory-disruption. 
The dynamic panel model of the determinant of financial performance of the SADC insurance sector is stated below:

$$
\begin{aligned}
& Y_{i t}=\beta_{1} X_{1 i t-1}+\beta_{2} X_{2 i t}+\beta_{3} X_{3 i t}+ \\
& +\beta_{4} X_{4 i t}+\beta_{5} X_{5 i t}+\beta_{6} X_{6 i t}+ \\
& +\beta_{7} X_{7 i t}+\beta_{8} X_{8 i t}+\beta_{9} X_{9 i t}+\mu_{i t},
\end{aligned}
$$

where $Y_{i t}$ is the depended variable; $X_{1 i t-1}$ denotes the lagged performance measure which signifies the dynamic dimension of the model. The study used the return on assets (ROA) as the dependent variable $(Y)$ to measure financial performance. $X_{2}-X_{9}$ are the independent variables (firm-specific). The independent variables were chosen based on the previous studies such as Sambasivam and Ayele (2013), Zainuddin et al. (2020). $\alpha_{0}$ is the intercept, $\beta_{1}-\beta_{9}$ are the coefficient, and $\mu_{i t}$ is the error term; it denotes it is a panel study. The variables used in this study are explicitly defined as shown in Table 1.

Thus, the model to be estimated in this study is stated as:

Table 1. Variable definition and measurement
$R O A_{i t}=\beta_{1} R O A_{1 i t-1}+\beta_{1} C L R_{1 i t}+$

$+\beta_{2} L E V_{2 i t}+\beta_{3} L I Q_{3 i t}+\beta_{4} \ln E Q C_{4 i t}+$

$+\beta_{5} I N V_{5 i t}+\beta_{6} \ln A G E_{6 i t}+$

$+\beta_{7} \ln S I Z_{7 i t}+\beta_{8} U N R_{8 i t}+\beta_{9} O P E_{9 i t}+\mu_{i t}$.

\section{EMPIRICAL RESULTS AND DISCUSSION}

Table 2 shows the descriptive results of the determinants of financial performance in African non-life insurance companies. Financial performance was measured by the return on assets and the determinants examined are firm-specific. The number of observations reveals that the panel is unbalanced as none of the variables have up to 1,452 as expected. The result reveals average values of 0.0228178 , $2.682895,1.333708,3.305809,0.7012148,1.552689$, $0.7405357,4.650519$, and 0.21063 for return on assets, equity capital, company age, company size, underwriting risk, operational efficiency, claims

\begin{tabular}{|c|c|c|c|}
\hline Definition & Notation & Formula & A priori \\
\hline Return on Assets & Y & Profit after tax/Total asset & \\
\hline Claim ratio & $\mathrm{X} 1 / \mathrm{CLR}$ & Claims Paid/Gross written premium & + \\
\hline Leverage ratio & X2/LEV & Total debt/Total equity & - \\
\hline Liquidity ratio & $X 3 / L I Q$ & Current asset/Current liability & + \\
\hline Equity Capital & $X 4 / E Q C$ & Log of equity capital & + \\
\hline Investment capability & X5/INV & Investment income/Total assets & + \\
\hline Company age & $X 6 / A G E$ & Log of the number of years since the establishment & + \\
\hline Company size & $X 7 / S I Z$ & Log of total asset & + \\
\hline Underwriting risk & X8/UNR & Benefit paid/Net premium & + \\
\hline Operational efficiency & X9/OPE & Ratio of expenditure to gross written premiums & + \\
\hline
\end{tabular}
ratio, leverage ratio, liquidity ratio, and investment capabilities, respectively. The values of stand-

\begin{tabular}{|c|c|c|c|c|c|}
\hline Variable & Observation & Mean & Std. Deviation & Minimum & Maximum \\
\hline$R O A$ & 1,437 & 0.0228178 & 0.0524069 & -0.317531 & 0.4461032 \\
\hline$E Q C$ & 1,438 & 2.682895 & 0.9551059 & 0.3881811 & 4.56672 \\
\hline$A G E$ & 1,439 & 1.333708 & 0.247498 & 0.30103 & 1.892095 \\
\hline SIZ & 1,437 & 3.305809 & 1.115611 & 0.8725677 & 5.62538 \\
\hline UNR & 1,387 & 0.7012148 & 0.4164824 & 0 & 4.333817 \\
\hline$O P E$ & 1,283 & 1.552689 & 2.769584 & 0.0395623 & 27.31277 \\
\hline$C L R$ & 1,276 & 0.7405357 & 1.347034 & -.1248122 & 18.1057 \\
\hline LEV & 1,438 & 4.650519 & 4.859315 & 0.0887884 & 29.72468 \\
\hline$\angle I Q$ & 1,433 & 0.21063 & 0.1957694 & 0 & 0.9460995 \\
\hline INV & 1,437 & 0.5575952 & 0.1977935 & 0.0004911 & 1.823402 \\
\hline
\end{tabular}

Table 2. Descriptive statistics 
Table 3. Correlation analysis

\begin{tabular}{|c|c|c|c|c|c|c|c|c|c|c|}
\hline & ROA & EQC & AGE & SIZ & RIS & OPE & CLR & LEV & LIQ & INV \\
\hline ROA & 1.000 & - & - & - & - & - & - & - & - & - \\
\hline EQC & $0.075 * * *$ & 1.000 & - & - & - & - & - & - & - & - \\
\hline$A G E$ & $-0.108 * * *$ & $0.123 * * *$ & 1.000 & - & - & - & - & - & - & - \\
\hline SIZ & -0.025 & $0.964 * * *$ & $0.157 * * *$ & 1.000 & - & - & - & - & - & - \\
\hline RIS & $-0.177^{* * *}$ & $0.321 * * *$ & $0.087 * * *$ & $0.431 * * *$ & 1.000 & - & - & - & - & - \\
\hline OPE & $-0.107 * * *$ & 0.009 & $-0.055 * *$ & $0.061 * *$ & $0.166^{* * *}$ & 1.000 & - & - & - & - \\
\hline CLR & $-0.098^{* * *}$ & 0.031 & -0.030 & $0.098^{* * *}$ & $0.107 * * *$ & $0.410 * * *$ & 1.000 & - & - & - \\
\hline LEV & $-0.255^{* * *}$ & $0.327 * * *$ & $0.105^{* * *}$ & $0.549 * * *$ & $0.542 * * *$ & $0.187 * * *$ & $0.252 * * *$ & 1.000 & - & - \\
\hline LIQ & $0.215^{* * *}$ & $-0.236 * * *$ & $-0.152 * * *$ & $-0.312 * * *$ & $-0.303^{* * *}$ & $-0.109 * * *$ & $-0.156 * * *$ & $-0.379 * * *$ & 1.000 & - \\
\hline INV & $0.168^{* * *}$ & $0.133^{* * *}$ & 0.039 & 0.135 & $0.235^{* * *}$ & $-0.039 * * *$ & $-0.068^{*}$ & $0.079 * * *$ & $-0.021^{* * *}$ & 1.000 \\
\hline
\end{tabular}

Note: $* * *, * *$ and $*$ mean significance $1 \%, 5 \%$ and $10 \%$ significant levels.

ard deviation are $0.0524069,0.9551059,0.247498$, 1.115611, 0.4164824, 2.769584, 1.347034, 4.859315, and 0.1957694 for variables return on assets, equity capital, company age, company size, underwriting risk, operational efficiency, claims ratio, leverage ratio, liquidity ratio, and investment capabilities, respectively. This shows the rate of deviations of the variables from the expected ratios. The minimum and maximum values are -0.317531 and $0.4461032 ; 0.3881811$ and $4.56672 ; 0.30103$ and 1.892095; 0.8725677 and 5.62538; 0 and 4.333817; 0.0395623 and $27.31277 ;-0.1248122$ and 18.1057 ; 0.0887884 and 29.72468; 0 and 0.9460995 for return on assets, equity capital, company age, company size, underwriting risk, operational efficiency, claims ratio, leverage ratio, liquidity ratio, and investment capabilities respectively.

The correlation coefficients presented in Table 3 show the degree of relationship that exists between the determinants (macroeconomic and firm-specific) and financial performance of non-life insurance companies in Africa. From the results, it was revealed that the company age, company size, underwriting risk, operational efficiency, claims ratio, leverage ratio, interest rate, and inflation rates are inversely correlated with return on assets to the tune of $-0.108,-0.025,-0.177,-0.107,-0.098$, $-0.255,-0.004$ and -0.087 , having company size insignificant. On the other hand, for equity capital, liquidity ratios, and investment capabilities, it was further discovered that the company age, company size, underwriting risk, leverage ratio, liquidity ratio, and investment capabilities are significantly correlated with equity capital, while operational efficiency and claims ratio are positively and insignificantly related to equity capital. Furthermore, it was discovered that the operational efficiency and liquidity ratio are inversely and significantly related to company age to the tune of -0.055 and -0.152 , while company size, underwriting risk, leverage ratio and exchange rate are positively and significantly related to company age to the tune of $0.157,0.087,0.105$ and -0.057 . From the perspective of company size, only investment capability has an insignificant but positive relationship to the tune of 0.135 . In all, none of the correlation coefficients is near the 0.8 threshold, which indicates that there is no signal of multicollinearity amongst the variables examined in this study.

The discussion in this paper is predicated on the two-step SYS-GMM estimator, which has several advantages. Firstly, it controls for time-invariant company-specific effects; secondly, it addresses the endogeneity problem of the lagged dependent variable; thirdly, it allows for some degree of endogeneity in the other regressors; and fourthly, it optimally combines information (Fukase, 2010). The two-step SYS-GMM revealed that the lagged return on assets has a positive and statistically significant impact on return on assets, confirming the model's dynamic character. This demonstrates that prior year financial performance has a substantial impact on the current year financial performance of non-life insurance companies, with a $Z$-statistic value of $3.13>2.58$. This is in line with Mutua and Atheru (2020).

Non-life insurance companies' financial performance in SADC countries is influenced by equity capital in an inverted and significant way. This indicates that these organizations' capital structures are unbalanced, as the result demonstrates the negative impact of using equity finance to fund their operations. Wanjugu (2012) in Kenya and 
Table 4. Regression analysis: OLS and two-step SYS-GMM

\begin{tabular}{|c|c|c|c|c|c|}
\hline \multirow{2}{*}{ Variable } & \multicolumn{2}{|c|}{ Two-step SYS-GMM } & \multicolumn{2}{|c|}{ POOLED OLS } & \multirow{2}{*}{$\begin{array}{l}\text { Decision on null hypotheses } \\
\text { based on two-step SYS-GMM }\end{array}$} \\
\hline & COEFF & STD ERR & COEFF & STD ERR & \\
\hline \multirow{2}{*}{ ROAL1 } & \multirow{2}{*}{0.4172599} & 0.1332178 & & & \multirow{2}{*}{ Reject } \\
\hline & & $(3.13)^{* * *}$ & & & \\
\hline \multirow{2}{*}{$E Q C$} & \multirow{2}{*}{-0.0011165} & 0.0004315 & \multirow{2}{*}{0.1292063} & 0.019448 & \multirow{2}{*}{ Reject } \\
\hline & & $(-2.59)^{* *}$ & & $(6.64)^{* * *}$ & \\
\hline \multirow{2}{*}{$A G E$} & \multirow{2}{*}{-0.0022268} & 0.0089087 & \multirow{2}{*}{0.0112565} & 0.0112432 & \multirow{2}{*}{ Accept } \\
\hline & & $(-0.25)$ & & $(1.00)$ & \\
\hline \multirow{2}{*}{$S I Z$} & \multirow{2}{*}{.0013519} & 0.0022193 & \multirow{2}{*}{-0.1134096} & 0.0198512 & \multirow{2}{*}{ Accept } \\
\hline & & $(0.61)$ & & $(-5.71) * * *$ & \\
\hline \multirow{2}{*}{$R I S$} & \multirow{2}{*}{-0.0042083} & 0.0079135 & \multirow{2}{*}{-0.0123929} & 0.0042052 & \multirow{2}{*}{ Accept } \\
\hline & & $(-0.53)$ & & $(-2.95)^{* * *}$ & \\
\hline \multirow{2}{*}{$O P E$} & \multirow{2}{*}{0.0011165} & 0.0004315 & \multirow{2}{*}{-0.0012706} & 0.0009645 & \multirow{2}{*}{ Reject } \\
\hline & & $(2.59)^{* *}$ & & $(-1.32)$ & \\
\hline \multirow{2}{*}{$C L R$} & \multirow{2}{*}{-0.0000697} & 0.0011699 & & 0.001497 & \\
\hline & & $(-0.06)$ & -0.0002599 & $(-0.17)$ & Accept \\
\hline & & 0.0004234 & & 0.0010699 & \\
\hline LEV & -0.0011136 & $(-2.63)^{* * *}$ & 0.0021126 & $(1.97)^{* *}$ & Reject \\
\hline & & 0.0126708 & & 0.0147673 & \\
\hline$\angle I Q$ & 0.0056286 & $(0.44)$ & -0.0339242 & $(-2.30)^{* *}$ & Accept \\
\hline & & 0.0057727 & & 0.0096345 & \\
\hline INV & 0.0218062 & $(3.78)^{* * *}$ & 0.0254305 & $(2.64)^{* * *}$ & Reject \\
\hline & (1) & 0.0000302 & (2073970 & 0.0121414 & \\
\hline constant & $0.0000 / 69$ & $(2.55)^{* * *}$ & 0.022391 & $(1.84)^{*}$ & \\
\hline $\begin{array}{l}\text { No. of } \\
\text { observation }\end{array}$ & & & & & \\
\hline No. of Group & & & & & \\
\hline $\begin{array}{l}\text { No. of } \\
\text { instrument }\end{array}$ & & & & & \\
\hline Wald chi2(14) & 712.2 & ) $* * *$ & & & \\
\hline Hansen test & Prob $>$ & 0.847 & & & \\
\hline Sargan Test & Prob $>c$ & $000 * * *$ & & & \\
\hline AR 1 & $\operatorname{Pr}>2$ & $0 * * *$ & & & \\
\hline AR 2 & $\operatorname{Pr}$ & 35 & & & \\
\hline & & & & $141)=13.25$ & $\left(u_{-} i, X b\right)=-0.4174$ \\
\hline Prob $>F$ & & & & 0.0 & \\
\hline Adj. $R^{2}$ & & & & & \\
\hline
\end{tabular}

Note: $* * *, * *$ and $*$ mean significance at $1 \%, 5 \%$ and $10 \%$ significant levels.

Ismail (2013) in Malaysia found that equity capital had a detrimental impact on financial performance. At 5\%, equity capital was noteworthy, with a $Z$-statistics of $2.59>1.96$.

The financial performance of SADC non-life insurers was found to be influenced by operational efficiency in a substantially beneficial manner. The implication of this conclusion is that insurance companies' operational efficiency is proportional to their financial performance. The ratio of total expenditure to gross written premium captures operational efficiency, which is a measure of input to output. This discovery found that SADC nonlife insurers' gross written premiums meet their expenses, indicating a stable and continuous financial performance. These finds are in line with those of Yu et al. (2014), Ongore and Kusa (2013), Feng et al. (2018), and Njuguna (2018).

The leverage ratio of $2.63>1.96$ has a detrimental and severe impact on non-life insurance companies' financial performance in SADC countries. This means that the more debt SADC non-life insurers use to conduct their business, the worse their financial performance would be. This finding contradicts the results of Adams and Buckle (2003), who discovered a positive effect of the leverage ratio on Bermuda insurance market financial performance; Diara (2015), who discovered a 
negligible effect of leverage on UK insurance companies; and Hidayat and Firmansyah (2017), who researched Indonesian insurance companies.

Furthermore, at a $1 \%$ significant level, investment capability has a strong and substantial effect on financial success as $3.78>1.96$. This result is consistent with Njeru (2018a) and Rajapathirana and Hui (2018). The greater the capability of investors to invest in a company, the better its financial performance. The beneficial impact of investment capability on financial performance in SADC non-life insurance companies demonstrates that the population is maximizing opportunities to invest and, on the other hand, that insurers are creating a large amount of room to invest, which tremendously and considerably enhances their financial performance. Size, on the other hand, has a favorable but minor impact on financial performance. The lack of relevance of size refutes conclusions of Malik (2011) and Mehari and Aemiro (2013). The size of a company has a direct impact on its financial performance since large companies can benefit from economies of scale, leading to improved performance and stability (Wani \& Ahmad, 2015).

Liquidity has a somewhat beneficial impact on financial performance success. This simply indicates that the more liquid the insurers are, the better their financial performance is, even though this is small in the context of SADC non-life insurers. This finding contradicts Malik (2011) findings from a Pakistani study. Moreover, this implies that cash is properly maintained to meet and satisfy quick requests for claims pending for payment in SADC non-life insurance businesses, implying that liquidity has a beneficial impact on the financial performance of the analyzed insurers. The financial performance and insurance company age have an unfavorable and minor impact. This goes against the a priori belief that an older insurance provider would profit from a track record of good performance. Nevertheless, this conclusion points to the prevalence of unaltered routines, a delayed response to changes in economic situations, and ineffectiveness. In an investigation conducted in India, Kaur and Kaur (2019) came to the same conclusion.

Underwriting risk, on the other hand, has an adverse and minor impact on financial performance. This disproves the premise of a priori anticipation and demonstrates that SADC non-life insurers' underwriting capacity is woefully inadequate. The implication is that the benefits are not covered by the net premium. The claims ratio has an adverse but minor impact on financial performance. This conclusion contradicts Mwangangi (2020) findings of investigation, as well as the a priori expectation. This also reveals that, in comparison to the total written premium derived, the claims paid to the insured are quite low.

Accordingly, 1,169 observations reveal that the panel is unbalanced and the fact that the number of instruments (93) is less than the number of groups (121) reveals that the findings of the twostep SYS-GMM are reliable. Similarly, the probability value of 0.847 revealed by the Hansen J statistic test shows the reliability of instruments specified and implies that there is no over-identification of instruments in the SYS-GMM. According to Oseni (2016), only the Hansen J test is relevant to determine the reliability of instruments specified in SYS-GMM. Hence, the Sargan J test is not required. Furthermore, the probability values of the Arrelano-Bond first and second order of serial correlation are 0.000 and 0.535 . This reveals that there is no serial correlation in the model specified.

\section{CONCLUSION AND POLICY IMPLICATIONS}

The firm-specific determinants of financial performance in SADC non-life insurance companies were investigated in this study. For the period from 2008 to 2019, 121 listed non-life insurance companies from 16 SADC nations were used. The two-step generalized method of moments analysis revealed that lagged return on assets, equity capital, operational efficiency, leverage ratio, and investment capability are the most important determinants of the financial performance of SADC's non-life insurance companies, while age, size, underwriting risk, claims ratio, and liquidity are insignificant. As a result of these studies, it is proposed that: 
- when making decisions and increasing financial performance, insurance companies, policymakers, governments, and investors must consider these important variables;

- cash and capital resources must be managed properly to reap the benefits of the associated economic benefits;

- the sector's capital structures should be modified to keep the equity and debt of the firms in a positive balance. The adverse effects of equity capital indicate that the insurance sector should focus more on using debt as a source of capital to grow its scale of operations;

- techniques such as automated systems that can lower operating costs must be implemented to improve financial performance;

- the sector's activities should be updated and reviewed regularly, as age has a minor but detrimental effect on financial performance. This is not intended to be the case, as a firm's longevity should help it create a reputation that allows policy-holders to effortlessly persuade them to acquire numerous policies, allowing insurance companies to grow their operations and enhance their financial performance.

This study is confined by the inability to have a balanced panel or use all the insurance sectors as some data are missing. However, this did not affect the findings' effectiveness. In addition, more research should be done on this topic using the life insurance industry as a case study so that findings from both the life and non-life insurance industries can be compared in the future. A study on many aspects of general insurance, such as motor, property, mobile, health, marine, and commercial insurance, can also be conducted. This will allow for comparability and the determination of which types of insurance are performing well and which take time and effort.

\section{AUTHOR CONTRIBUTIONS}

Conceptualization: Thabiso Sthembiso Msomi.

Data curation: Thabiso Sthembiso Msomi, Celani John Nyide.

Formal analysis: Thabiso Sthembiso Msomi, Celani John Nyide.

Investigation: Thabiso Sthembiso Msomi.

Methodology: Thabiso Sthembiso Msomi.

Project administration: Thabiso Sthembiso Msomi.

Supervision: Celani John Nyide.

Validation: Thabiso Sthembiso Msomi, Celani John Nyide.

Visualization: Thabiso Sthembiso Msomi, Celani John Nyide.

Writing - original draft: Thabiso Sthembiso Msomi.

Writing - review \& editing: Celani John Nyide.

\section{REFERENCES}

1. Abdeljawad, I., Dwaikat, L. M., \& Oweidat, G. (2020). The determinants of profitability of insurance companies in Palestine. An-Najah University Journal for Research-B (Humanities), 36(2). http://dx.doi.org/10.2139/ ssrn. 3533345

2. Adams, M., \& Buckle, M. (2003). The determinants of corporate financial performance in the Bermuda insurance market. Applied Financial Economics, 13(2), 133-143. https://doi. org/10.1080/09603100210105030

3. Ahmed, U., Khalid, N., Ahmed, A., \& Shah, M. H. (2017). Assessing moderation of employee engagement on the relationship between work discretion, job clarity and business performance in the banking sector of Pakistan. Asian Economic and Financial Review, 7(12), 1197-1210. Retrieved from https://ideas.repec. org/a/asi/aeafrj/2017p1197-1210. html

4. Alhassan, A. L., \& Biekpe, N. (2017). Liberalization outcomes and competitive behaviour 
in an emerging insurance market. African Development Review, 29(2), 122-138. https://doi. org/10.1111/1467-8268.12245

5. Aliabadi, S., Dorestani, A., \& Balsara, N. (2013). The most value relevant accounting performance measure by industry. Journal of Accounting and Finance, 13(1), 22-34. Retrieved from http://www. na-businesspress.com/JAF/aliabadi_abstract.html

6. Almajali, A. Y., Alamro, S. A., \& Al-Soub, Y. Z. (2012) Factors affecting the financial performance of Jordanian insurance companies listed at Amman Stock Exchange. Journal of Management research, 4(2), 266. http://dx.doi.org/10.5296/jmr. v4i2.1482

7. Alomari, M. W., \& Azzam, I. A. (2017). Effect of the micro and macro factors on the performance of the listed Jordanian insurance companies. International Journal of Business and Social Science, 8(2), 66-73. Retrieved from https:// www.ijbssnet.com/journals/Vol_8_ No_2_February_2017/9.pdf

8. Arellano, M., \& Bond, S. (1991). Some tests of specification for panel data: Monte Carlo evidence and an application to employment equations. The review of economic studies, 58(2), 277-297. https://doi. org/10.2307/2297968

9. Asongu, S. A., Uduji, J. I., \& Okolo-Obasi, E. N. (2019). Fighting African capital flight: trajectories, dynamics, and tendencies. Financial Innovation, 14(6), 1-21. Retrieved from https://mpra. ub.uni-muenchen.de/102034/

10. Badea, I. (2017). Literature Review on the Determinants of Insurers' Financial Performance. Annals of the Constantin Brâncuşi" University of Târgu Jiu: Economy Series, Special Issue, 1(29), 34-39.

11. Bashatweh, A. D., \& Ahmed, E. Y. (2020) Financial performance evaluation of the commercial banks in Jordan: Based on the CAMELS framework. International Journal of Advanced Science and Technology, 29(5), 985-994. Retrieved from http:// sersc.org/journals/index.php/ IJAST/article/view/9752
12. Batool, A., \& Sahi, A. (2020).

Determinants of financial performance of insurance companies of USA and UK during global financial crisis (2007-2016). International Journal of Accounting Research, 8(3), 1-9.

13. Berger, A. N., \& Humphrey, D. B. (1997). Efficiency of financial institutions: International survey and directions for future research. European journal of operational research, 98(2), 175212. https://doi.org/10.1016/ S0377-2217(96)00342-6

14. Berhe, T. A., \& Kaur, J. (2017). Determinants of insurance companies' profitability: Analysis of insurance sector in Ethiopia. International journal of research in finance and marketing (IJRFM), 7(4), 124-137.

15. Berteji, A., \& Hammami, S. (2016). The determinants of the performance of the life insurance companies in Tunisia. International journal of economics, commerce and management, 4(7), 2348-2386.

16. Blundell, R., \& Bond, S. (1998) Initial conditions and moment restrictions in dynamic panel data models. Journal of econometrics, 87(1), 115-143. https://doi.org/10.1016/S03044076(98)00009-8

17. Burca, A. M., \& Batrinca, G. (2014). The determinants of financial performance in the Romanian insurance market. International Journal of Academic Research in Accounting, Finance and Management Sciences, 4(1), 299-308. http://dx.doi. org/10.6007/IJARAFMS/v4-i1/637

18. Chen, M. J., Michel, J. G., \& Lin, W. (2021). Worlds apart? Connecting competitive dynamics and the resource-based view of the firm. Journal of Management, 47(7), 1820-1840. https://doi.org/1 0.1177\%2F01492063211000422

19. Daly, F., Teague, P., \& Kitchen, P. (2003). Exploring the role of internal communication during organizational change. Corporate Communications: An International Journal, 8(3), 153-162. https://doi. org/10.1108/13563280310487612
20. Davis, G. F. (2010). The twilight of the Berle and Means corporation. Seattle UL Review, 34, 1121. Retrieved from https:// papers.ssrn.com/sol3/papers. cfm?abstract_id=1860097

21. Egbunike, C. F., \& Okerekeoti, C. U. (2018). Macroeconomic factors, firm characteristics and financial performance: A study of selected quoted manufacturing firms in Nigeria. Asian Journal of Accounting Research, 3(2), 142-168. https://doi.org/10.1108/AJAR-092018-0029

22. Epps, R. W., \& Cereola, S. J. (2008). Do institutional shareholder services (ISS) corporate governance ratings reflect a company's operating performance? Critical Perspectives on Accounting, 19(8), 1135-1148. http://dx.doi.org/10.1016/j. cpa.2007.06.007

23. Feng, M., Yu, W., Wang, X., Wong, C. Y., Xu, M., \& Xiao, Z. (2018). Green supply chain management and financial performance: The mediating roles of operational and environmental performance. Business Strategy and the Environment, 27(7), 811-824. https://doi.org/10.1002/bse.2033

24. Finmark Trust. (2019). Fin Scope South Africa 2019 Pocket Guide. Retrieved June 20, 2020, from https://finmark.org.za/system/ documents/files/000/000/242/ original/FinScope_SA_2019_ Pocket_Guide_2020. pdf?1604679365

25. Fukase, E. (2010). Revisiting linkages between openness, education and economic growth: System GMM approach. Journal of Economic Integration, 193-222.

26. Greene, W. H. (2003). Econometric analysis. Pearson Education India.

27. Havnes, P. A., \& Senneseth, K. (2001). A panel study of firm growth among SMEs in networks. Small business economics, 16(4), 293-302. Retrieved from https:// www.jstor.org/stable/40229159

28. Heid, B., Langer, J., \& Larch, M. (2012). Income and democracy: Evidence from system GMM estimates. Economics Letters, 116(2), 166-169. 
29. Hidayat, I. P., \& Firmansyah, I. (2017). Determinants of financial performance in the Indonesian Islamic insurance industry. Etikonomi, 16(1), 194871. http://dx.doi.org/10.15408/etk v16i1.4648

30. Hsieh, H. P., Wu, Y. C., Lu, W. M., \& Chen, Y. C. (2020). Assessing and ranking the innovation ability and business performance of global companies in the aerospace and defense industry. Managerial and Decision Economics, 41(6), 952-963. https://doi.org/10.1002/ mde. 3150

31. Ibhagui, O. W., \& Olokoyo, F. O. (2018). Leverage and firm performance: New evidence on the role of firm size. The North American Journal of Economics and Finance, 45, 57-82. https://doi org/10.1016/j.najef.2018.02.002

32. Ibrahim, Y., Ahmed, I., \& Minai, M. S. (2018). The influence of institutional characteristics on financial performance of microfinance institutions in the OIC countries. Economics and Sociology, 11(2), 19-35. https://doi.org/10.14254/2071789X.2018/11-2/2

33. Ismail, M. (2013). Determinants of financial performance: The case of general takaful and insurance companies in Malaysia. International Review of Business Research Papers, 9(6), 111-130.

34. Jadi, D. M. (2015). An empirical analysis of determinants of financial performance of insurance companies in the United Kingdom (Doctoral disseration). University of Bradford.

35. Jensen, M. C., \& Meckling, W. H. (1976). Theory of the firm: Managerial behavior, agency costs and ownership structure. Journal of Financial Economics, 3(4), 305 360. https://doi.org/10.1016/0304405X(76)90026-X

36. Junaid, M., Xue, Y., Syed, M. W., Ziaullah, M., \& Riffat, N. (2020). Corporate governance mechanism and performance of insurers in Pakistan. Green Finance, 2(3), 243-262. https://doi.org/10.3934/ GF.2020014
37. Kariuki, P., \& Nguyo, R. (2020). Firm Level Factors and Organization Performance: the Moderating Role of Industry Environment. Journal of International Business and Management, 3(3), 1-13. Retrieved from https://rpajournals.com/wpcontent/uploads/2020/06/JIBM2019-04-127.pdf

38. Kaur, A., \& Kaur, R. (2019). Web disclosure of corporate social responsibility: a study of Indian insurance companies. International Journal of Banking, Risk and Insurance, 7(1), 13-24. Retrieved from https://www.proquest.com/openview/f94434b07b 564268334aed74dd1cdb30/1?pqorigsite $=$ gscholar $\& \mathrm{cbl}=2043515$

39. Killins, R. N. (2020). Firmspecific, industry-specific and macroeconomic factors of life insurers' profitability: Evidence from Canada. The North American Journal of Economics and Finance, 51, 101068. https://doi. org/10.1016/j.najef.2019.101068

40. Kutu, A. A., \& Ngalawa, H. (2016). Monetary policy shocks and industrial sector performance in South Africa. Journal of Economics and Behavioral Studies, $8(3(\mathrm{~J}))$, 2640. http://dx.doi.org/10.22610/jebs. v8i3(J).1286

41. Lambert, R. A. (2001).

Contracting theory and accounting. Journal of accounting and economics, 32(1-3), 3-87. https://doi.org/10.1016/S01654101(01)00037-4

42. Lingesiya, Y. (2020). Determinants effecting companies' leverage: A study of panel data in Sri Lanka. ACADEMICIA: An International Multidisciplinary Research Journal, 10(6), 377-388. http://dx.doi.org/10.5958/22497137.2020 .00712 .0

43. Malik, H. (2011). Determinants of insurance companies' profitability: an analysis of insurance sector of Pakistan. Academic research international, 1(3), 315-321. Retrieved from http://www. savap.org.pk/journals/ARInt./ Vol.1(3)/2011(1.3-32)stop.pdf

44. Mazviona, B. W., Dube, M., \& Sakahuhwa, T. (2017). An analysis of factors affecting the performance of insurance companies in Zimbabwe. Journal of Finance and Investment Analysis, 6(1), 1-21. Retrieved from https://ideas.repec.org/a/spt/ fininv/v6y2017i1f6_1_2.html

45. Mehari, D., \& Aemiro, T. (2013). Firm specific factors that determine insurance companies' performance in ethiopia. European scientific journal, 9(10).

46. Mlambo, V. H. (2020). Consolidating Regional Integration Through a Free Movement Protocol: The Quest for Collective Development in the SADC. African Journal of Governance \& Development, 9(2), 455-471. Retrieved from https:// journals.ukzn.ac.za/index.php/ jgd/article/view/1918

47. Morosan, C., Hua, N., \& Defranco, A. (2017). E-commerce expenses and financial performance of american upper midscale hotels. Tourism Analysis, 22(3), 295-308. https://doi.org/10.3727/10835421 7X14955605216041

48. Musah, M., Kong, Y., \& Mensah, I. A. (2019). Exploring the link between operational efficiency and firms' financial performance: An empirical evidence from the Ghana Stock Exchange (GSE). International Journal of Trend in Scientific Research and Development, 3(4), 1-7. http:// dx.doi.org/10.31142/ijtsrd23954

49. Mutua, L. M., \& Atheru, G. K. (2020). Capital Structure and Financial Performance of Companies listed under Manufacturing and Allied Sector at Nairobi Securities Exchange in Kenya. Journal of Finance and Accounting, 4(1), 24-38.

50. Mwakajila, H. M., \& Nyello, R. M. (2021). Leadership Styles, Firm Characteristics and Business Financial Performance of Small and Medium Enterprises (SMEs) in Tanzania. Open Journal of Business and Management, 9(4), 1696-1713. https://doi. org/10.4236/ojbm.2021.94093

51. Mwangangi, J. (2020). Effect of underwriting results on profitability of General Insurance Industry 
in Kenya (Doctoral disseration). University of Nairobi.

52. Mwangi, M., \& Murigu, J.W. (2015). The determinants of financial performance in general insurance companies in Kenya. European Scientific Journal, 2(1), 288-297.

53. Nhabinde, S., \& Heshmati, A. (2020). The Extractive Industry's Impact on Economic Growth in SADC Countries (IZA Discussion Paper No. 13586). Retrieved from https://ssrn.com/abstract $=3674307$

54. Njeri, A. (2017). Effects of innovation strategy on firm performance in telecommunications industry: A case of Safaricom Kenya limited (Doctoral dissertation). United States International UniversityAfrica.

55. Njeru, M. D. (2016). Effect of Liquidity Management on financial performance of Deposit Taking Saving and credit co-operative society in Kenya (Doctoral dissertation). Jomo Kenyatta University of Agriculture and Technology.

56. Njeru, P. W. (2018a). Redefining the substantive and procedural protections of Most Favoured Nation clauses in Bilateral Investment Treaties (BITs) (Doctoral dissertation). Strathmore University.

57. Njeru, T. (2018b). An Investigation of the factors influencing the financial performance of non-life insurance business in Kenya (Doctoral dissertation). Strathmore University.

58. Njuguna, A. M. (2018). Effect of Working Capital Management on Financial Performance of Construction and Allied Sector Firms Listed in the Nairobi Securities Exchange for the Period 2012-2016 (Doctoral dissertation). United States International University-Africa.

59. Nnenna, O. V., Chukwuma, U. C., \& Ifeanyi, N. C. (2020). Financial Determinants of Liquidity Positions of Listed Manufacturing Firms on the Nigerian Stock
Exchange. European Journal of Business and Management, 12(14), 56-65. Retrieved from https://1library.net/document/ y9003dvy-financial-determinants-liquidity-positions-listedmanufacturing-nigerian-exchange. html

60. Olarewaju, O. M., \& Msomi, T. S. (2021). Intellectual capital and financial performance of South African development community's general insurance companies. Heliyon, 7(4), e06712. https://doi. org/10.1016/j.heliyon.2021.e06712

61. Ongore, V. O., \& Kusa, G. B. (2013). Determinants of financial performance of commercial banks in Kenya. International journal of economics and financial issues, 3(1). Retrieved from https:// www.econjournals.com/index. php/ijefi/article/view/334

62. Oppong, G. K., Pattanayak, J. K., \& Irfan, M. (2019). Impact of intellectual capital on productivity of insurance companies in Ghana: A panel data analysis with system GMM estimation. Journal of Intellectual Capital, 20(6), 763-783. https://doi.org/10.1108/JIC-122018-0220

63. Oseni, I. O. (2016). Exchange rate volatility and private consumption in Sub-Saharan African countries: A system-GMM dynamic panel analysis. Future Business Journal, 2(2), 103-115.

64. Padayachee, N., Rothberg, A. D., Truter, I., \& Butkow, N. (2019). Utilization of over-the-counter analgesics in two private medical insurance schemes in South Africa. Drug, healthcare and patient safety, 11, 37-45. Retrieved from https://www.ncbi.nlm.nih. gov/pmc/articles/PMC6645681/

65. Padayachee, V., \& Van Niekerk, R. (2019). Shadow of Liberation: contestation and compromise in the economic and social policy of the African National Congress, 1943-1996. Wits University Press.

66. Padmavathi, K., \& Thangadurai, K. (2016). Implementation of RGB and grayscale images in plant leaves disease detectioncomparative study. Indian Journal of Science and Technology, 9(6),
1-6. http://dx.doi.org/10.17485/ ijst/2016/v9i6/77739

67. Raifu, I. (2019). Economic growth in Africa: Does gender education still matter? Education and Economic Development. Retrieved from https://mpra.ub.unimuenchen.de/id/eprint/92916

68. Rajapathirana, R. J., \& Hui, Y. (2018). Relationship between innovation capability, innovation type, and firm performance. Journal of Innovation \& Knowledge, 3(1), 44-55. https://doi. org/10.1016/j.jik.2017.06.002

69. Robins, J., \& Wiersema, M. F. (1995). A resource-based approach to the multibusiness firm: Empirical analysis of portfolio interrelationships and corporate financial performance. Strategic management journal, 16(4), 277-299. https://doi. org/10.1002/smj.4250160403

70. Saeidi, S. P., Othman, M. S. H., Saeidi, P., \& Saeidi, S. P. (2018). The moderating role of environmental management accounting between environmental innovation and firm financial performance. International Journal of Business Performance Management, 19(3), 326-348. http://dx.doi. org/10.1504/IJBPM.2018.092759

71. Sambasivam, Y., \& Ayele, A. G. (2013). A study on the performance of insurance companies in Ethiopia. International Journal of Marketing, Financial Services \& Management Research, 2(7), 138-150.

72. Sangmi, M. U. D., \& Nazir, T. (2010). Analyzing financial performance of commercial banks in India: Application of CAMEL model. Pakistan Journal of Commerce and Social Sciences (PJCSS), 4(1), 40-55. Retrieved from https://www.econstor.eu/ handle/10419/187999

73. Shiu, Y. M. (2020). How does reinsurance and derivatives usage affect financial performance? Evidence from the UK non-life insurance industry. Economic Modelling, 88, 376-385. http:// doi.org/10.1016/j.econmod.2019.09.048 
74. Teece, D., Peteraf, M., \& Leih, S. (2016). Dynamic capabilities and organizational agility: Risk, uncertainty, and strategy in the innovation economy. California management review, 58(4), 13-35. https://doi. org/10.1525\%2Fcmr.2016.58.4.13

75. Wani, A. A., \& Ahmad, S. (2015). Relationship between financial risk and financial performance: An insight of Indian insurance industry. International Journal of Science and Research, 4(11), 1424-1433.

76. Wanjugu, M. J. (2012). The Determinants of Financial Performance in General Insurance Companies in Kenya (Thesis). University of Nairobi.
77. Wongchai, A. (2017). The operational efficiency analysis of insurance companies in Thailand. Advanced Science Letters, 23(11), 10632-10635. http://dx.doi. org/10.1166/asl.2017.10118

78. Yassin, M. (2021). Investigating the Effects of Board and Firm Characteristics on Firm Performance: An Agency Theory Perspective. Scientific Journal for Financial and Commercial Studies and Researches, 2(1/1), 228-264. https://dx.doi.org/10.21608/ cfdj.2020.129333

79. Yu, W., Ramanathan, R., \& Nath, P. (2014). The impacts of marketing and operations capabilities on financial performance in the UK retail sector: A resource-based perspective. Industrial Marketing Management, 43(1), 25-31. https://doi.org/10.1016/j.indmarman.2013.07.014

80. Zainuddin, M., Mahi, M., Akter, S., \& Yasin, I. M. (2020). The role of national culture in the relationship between microfinance outreach and sustainability: a correlated random effects approach. Cross Cultural \& Strategic Management, 27(3), 447-472. https://doi. org/10.1108/CCSM-12-2019-0219

81. Zuhroh, I. (2019). The Effects of Liquidity, Firm Size, and Profitability on the Firm Value with Mediating Leverage. The 2nd International Conference on Islamic Economics, Business, and Philanthropy, 203-230. Retrieved from https://knepublishing.com/ index.php/Kne-Social/article/ view/4206 